BUDGETING : Journal of Business, Management and Accounting

Volume 2, Nomor 1, Desember 2020

e-ISSN: 2715-2480

p-ISSN: 2715-1913

DOI : https://doi.org/10.31539/budgeting.v2i1.1761

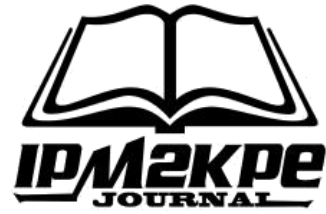

\title{
EFISIENSI BIAYA PRODUKSI DENGAN MENGGUNAKAN METODE TARGET COSTING DALAM MENINGKATKAN LABA
}

\author{
Yogi Lesmana ${ }^{1}$, Erry Sunarya $^{2}$, Nor Norisanti $^{3}$ \\ Universitas Muhammadiyah Sukabumi ${ }^{1,2,3}$ \\ ylesmana503@gmail.com ${ }^{1}$
}

\begin{abstract}
ABSTRAK
Tujuan dari penelitian ini adalah untuk mengetahui bagaimana penetapan biaya produksi dan pendapatan UKM Kripset UMMI Sukabumi, untuk menganalisis efisiensi biaya produksi dengan menggunakan metode target costing untuk meningkatkan laba pada UKM Kripset UMMI Sukabumi. Penelitian ini menggunakan metode target costing untuk mengefesiensikan biaya produksi UKM Kripset UMMI Sukabumi. Hasil penelitian menunjukkan bahwa sebelum penerapan target costing, UKM Kripset UMMI Sukabumi menghabiskan biaya produksi sebesar Rp. 58.320.000 dan setelah penerapan target costing, biaya menjadi Rp. 54.200.000. Maka dari itu, perusahaan bisa mengefesiensikan biaya sebesar Rp. 4.120.000. Laba yang diperoleh perusahaan sebelumnya adalah sebesar Rp. 1.680.000. Kemudian setelah menggunakan metode target costing, laba perusahaan meningkat sebesar Rp.5.800.000. Simpulan, penetapan biaya produksi di UKM Kripset UMMI Sukabumi masih menggunakan metode manual, sehingga biaya produksi UKM terus meningkat dan laba yang diperoleh belum optimal. Namun setelah penerapan target costing, biaya produksi bisa diefisiensikan dan peningkatan laba yang diperoleh pun cukup signifikan.
\end{abstract}

Kata Kunci: Biaya Produksi, Laba, Target Costing

\section{ABASTRACT}

The purpose of this study was to determine how the determination of production costs and income of UKM Kripset UMMI Sukabumi, to analyze the efficiency of production costs using the target costing method to increase profits at UKM Kripset UMMI Sukabumi. This study uses the target costing method to streamline the production costs of SME Kripset UMMI Sukabumi. The results showed that before the application of target costing, UKM Kripset UMMI Sukabumi spent a production cost of Rp. 58,320,000 and after the application of target costing, the cost became Rp. 54,200,000. Therefore, the company can streamline costs of Rp. 4,120,000. The profit obtained by the previous company was $R p$. 1,680,000. Then after using the target costing method, the company's profit increased by Rp. 5,800,000. In conclusion, the determination of production costs at UKM Kripset UMMI Sukabumi still uses the manual method, so that the production costs of SMEs continue to increase and the profits obtained are not optimal. However, after the application of target costing, production costs can be streamlined and the increase in profits obtained is quite significant.

Keywords: Production Costs, Profits, Target Costing 


\section{PENDAHULUAN}

Usaha Kecil dan Menengah (UKM) merupakan suatu usaha kecil yang dibentuk oleh seseorang di lingkungan masyarakat. Masyarakat yang dimaksud disini adalah mereka yang belum termasuk sebagai golongan atas. UKM berperan sangat penting sebagai penyedia lapangan pekerjaan dan bisa meminimalisir tingkat pengangguran yang ada di Indonesia. Tidak adanya standar ijazah untuk para karyawan membuat masyarakat lebih mudah untuk mendapatkan pekerjaan. Selain itu bisnis UKM juga berperan dalam pertumbuhan ekonomi suatu negara.

Umumnya tujuan dari sebuah usaha adalah mendapatkan laba yang maksimal. Besar kecilnya perolehan laba merupakan ukuran keberhasilan manajemen dalam mengelola usaha. Biaya dalam proses produksi juga sangat berpengaruh dalam perolehan laba perusahaan, untuk itu biaya produksi harus diperhatikan untuk mencapai tujuan perusahaan tersebut. Pengendalian biaya harus diselaraskan terhadap tujuan yang ingin dicapai oleh perusahaan. Salah satu tujuan yang ingin dicapai oleh perusahaan adalah memperoleh laba yang maksimal dengan mengeluarkan biaya yang serendahrendahnya. Oleh karena itu dengan mengendalikan biaya produksi, perusahaan berharap akan mendapatkan laba yang maksimal. Untuk dapat bersaing dalam lingkungan pasar, perusahaan tersebut pun dituntut agar dapat menciptakan suatu inovasi produk yang baik dan harganya lebih rendah atau paling tidak sama dengan harga yang ditawarkan oleh para pesaingnya.

Masalah yang sering dihadapi oleh suatu perusahaan salah satunya yaitu naiknya harga-harga biaya pada proses produksi, dimana harga biaya-biaya yang dikeluarkan dalam proses produksi sangat berpengaruh pada pendapatan perusahaan sehingga laba yang dihasilkan perusahaan menurun. Jika hal ini terus terjadi, maka tidak menutup kemungkinan para pelaku usaha akan terus mengalami kerugian dan bahkan tidak dapat melanjutkan usahanya. Oleh karena itu diperlukan solusi agar perusahaan bisa menghadapi permasahalan tersebut. Metode yang dapat digunakan untuk mengefisiensikan biaya yang disebabkan oleh kenaikan biaya-biaya dalam produksi adalah metode target costing.

Target costing merupakan metode penentuan biaya produksi dimana perusahaan terlebih dahulu menentukan biaya produksi yang harus dikeluarkan berdasarkan harga kompetitif. Dengan demikian perusahaan memperoleh laba yang diharapkan. Mengingat 
begitu penting target costing, maka hal ini perlu diperhatikan oleh perusahaan dalam menjalankan kegiatan produksi sesuai dengan yang target yang diinginkan. Tujuan yang ingin dicapai oleh perusahaan dengan menerapkan target costing adalah untuk mengefesiensikan biaya-biaya dalam suatu proses produksi tanpa merubah kualitas dari suatu produk. Hal ini sangat baik untuk diterapkan oleh perusahaan agar perusahaan dapat mengelola biaya (cost management) dengan baik, mengingat sekarang harga bahan baku semakin melonjak naik.

Pendekatan perhitungan target costing ini dikembangkan berdasarkan dua karakteristik penting. Pertama yaitu perusahaan tidak dapat mengendalikan harga, pasarlah yang menentukan harga. Karakteristik yang kedua adalah sebagian besar biaya produk ditentukan pada tahap desain. Saat yang paling tepat untuk mengurangi biaya umumnya pada tahap desain, dimana pada ini perusahaan dapat menentukan bahanbahan apa yang akan digunakan dalam memproduksi barangnya (bahan yang murah dengan kualitas yang baik dan sesuai kriteria). Dengan begitu, perusahaan dapat menentukan laba yang diinginkan serta mengendalikan biaya yang akan terjadi dalam memproduksi barang agar tercipta harga yang ditetapkan.

UKM Kripset UMMI merupakan salah satu UKM yang bergerak di bidang makanan dan telah tercatat di Dinas Koperasi dan Usaha Kecil Menengah Provinsi Jawa Barat dengan Nomor: 002.6/456/DISKOP.UKM. UKM ini juga telah memiliki sertifikat halal dari Majelis Ulama Indonesia dengan Nomor : 01101041110609.

Berikut ini merupakan grafik biaya bahan baku produksi yang digunakan oleh UKM Kripset UMMI Sukabumi pada tahun 2018 yang disajikan pada gambar 1.

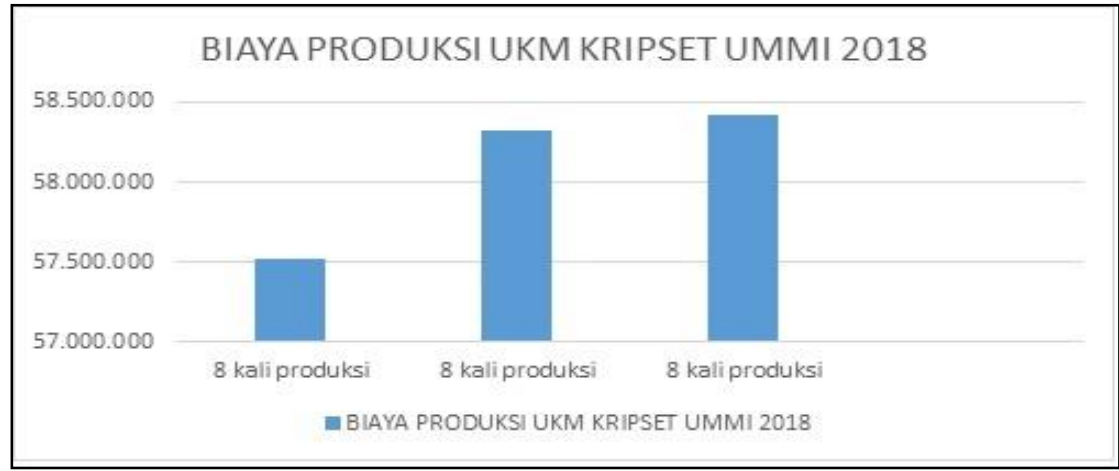

Gambar 1.

Biaya Produksi UKM Kripset UMMI 2018 
Berdasarkan hasil analisis peneliti dengan pemilik UKM, ditemukan sebuah permasalahan yaitu pemilik perusahaan belum menggunakan metode target costing dalam usahanya. Selama ini UKM menggunakan metode standar costing sehingga dalam pengelolaan manejemen keuangan, UKM ini masih belum terstruktur dalam pengelolaan biaya produksi. Ketika biaya produksi semakin melonjak, UKM ini belum bisa menentukan biaya maksimum yang dimungkinkan bagi pembuatan sebuah produk. Melonjak naiknya biaya produksi ini berpengaruh besar bagi perolehan laba UKM Kripset UMMI ini. Oleh karena itu, peneliti ingin mencoba untuk menerapkan metode target costing tersebut guna memaksimalkan laba UKM Kripset UMMI.

\section{KAJIAN TEORI}

\section{Manajemen Keuangan}

Menurut Sutrisno (2013) manajemen keuangan merupakan semua aktivitas perusahaan yang berhubungan dengan usaha-usaha mendapatkan dana perusahaan dengan biaya yang murah serta usaha untuk menggunakan dan mengalokasikan dana tersebut secara efisien. Sedangkan menurut Kamaludin \& Indriani (2012) manajemen keuangan adalah upaya dan kegiatan dalam rangka meningkatkan nilai perusahaan. Selain itu manajemen keuangan merupakan upaya untuk mendapatkan dana dengan cara yang paling menguntungkan serta mengalokasikan dana secara efisien dalam perusahaan sebagai sarana bagi kekayaan pemegang saham.

Menurut Riyanto (2013) keseluruhan aktivitas yang bersangkutan dengan usaha untuk mendapatkan dana dan menggunakan atau mengaloksikan dana tersebut disebut sebagai pembelanjaan perusahaan dalam artian yang luas (business financial) atau manajemen keuangan (financial management). Sedangkan pembelanjaan dalam artian sempit adalah aktivitas yang hanya bersangkutan dengan usaha untuk mendapatkan dana saja atau sering disebut sebagai pembelanjaan pasif atau pendanaan (financing).

Menurut Copelan \& Weston (1992) terdapat tiga tugas pokok manajemen keuangan, diantaranya yaitu: meliputi pembiayaan kegiatan usaha, keputusan investasi dan pembagian dividen dalam suatu perusahaan. Dengan demikian, dapat disimpulkan bahwa manajemen keuangan adalah kegiatan untuk mendapatkan dana agar dapat meningkatkan nilai perusahaan dan untuk menguntungkan pemegang saham di perusahaan. Manajemen keuangan lebih mengarah pada usaha untuk mendapatkan dana, 
pengeluaran biaya yang murah dan menggunakan dana seefesien mungkin. Manajemen keuangan memiliki tiga tugas penting yaitu pembiayaan kegiatan usaha, keputusan investasi dan pembagian dividen dalam suatu perusahaan.

\section{Biaya}

Menurut Ahmad \& Abdullah (2009) biaya (cost) adalah pengeluaranpengeluaran atau nilai pengorbanan untuk memperoleh barang dan jasa yang berguna untuk masa yang akan datang atau mempunyai manfaat melebihi satu periode akuntansi tahunan. Sedangkan beban (expense) adalah biaya yang telah memberikan suatu manfaat dan termasuk pula penurunan dalam aset atau kenaikan dalam kewajiban sehubungan dengan penyerahan barang dan jasa dalam rangka memperoleh pendapatan.

Menurut Bustami \& Nurlela (2010) pengertian biaya dan beban sebagai berikut: 1) biaya (cost), yaitu pengorbanan sumber ekonomi yang diukur dalam satuan uang yang telah terjadi atau kemungkinan akan terjadi untuk mencapai tujuan tertentu. Biaya ini belum habis masa pakainya dan digolongkan sebagai aktiva yang dimasukkan kedalam neraca; 2) beban (expense) merupakan biaya yang telah memberikan manfaat dan sekarang telah habis. Biaya yang belum dinikmati yang dapat memberikan manfaat di masa yang akan datang dikelompokkan sebagai harta. Beban ini dimasukkan kedalam laporan laba atau rugi dan sebagai pengurangan pendapatan.

Menurut Mulyadi (2012) pengertian biaya dalam arti luas adalah pengorbanan yang diukur dalam satuan uang untuk mencapai tujuan tertentu. Adapun biaya dalam arti sempit yaitu harga pokok dalam usaha untuk memperoleh penghasilan. Dengan demikian dapat disimpulkan bahwa biaya adalah kas yang digunakan untuk membuat barang/jasa bernilai jual yang diharapkan bisa memberikan keuntungan dan manfaat bagi pelaku usaha. Kemudian beban adalah sesuatu dikeluarkan untuk memproduksi suatu barang/jasa sehingga dapat diperjual belikan yang mempunyai manfaat dan menjadi nilai pendapatan. 


\section{Biaya Produksi}

Menurut Haryono (2009) biaya produksi adalah fungsi pokok perusahaan bersifat lebih kompleks dibandingkan dengan perusahaan dagang atau jasa karena perusahaan harus mengubah produk yang dibeli menjadi produk yang siap pakai. Sedangkan perusahaan dagang tidak perlu mengubah produk yang dibeli menjadi produk jadi atau siap pakai.

Menurut Mulyadi (2012) biaya produksi adalah biaya-biaya yang terjadi dalam hubungannya dengan proses pengolahan bahan baku menjadi produk jadi. Menurut Hansen \& Mowen (2004) biaya produksi adalah pengeluaran biaya yang berkaitan dengan proses pembuatan barang ataupun penyediaan jasa. Nafarin (2009) menyatakan bahwa biaya produksi adalah semua biaya yang berkaitan dengan produk (barang) yang diperoleh, dimana di dalamnya terdapat unsur biaya produk beruapa biaya bahan baku, biaya tenaga kerja langsung, dan biaya overhead pabrik. Oleh karena itu, dapat disimpulkan bahwa biaya produksi adalah semua biaya yang berhubungan dengan fungsi produksi untuk menghasilkan produk atau barang jadi. Dengan adanya perencanaan biaya produksi, maka hal tersebut dapat membantu perusahaan dalam memperkirakan pengeluaran biaya untuk bahan baku, jumlah biaya untuk tenaga kerja dan biaya overhead di perusahaan.

\section{Laba}

Menurut Nafarin (2009) laba (income) adalah perbedaan antara pendapatan dengan keseimbangan biaya-biaya dan pengeluaran untuk periode tertentu. Perhitungan laba diperoleh dari pendapatan dikurangi semua biaya (Kuswadi, 2005). Menurut Hanafi (2010) laba merupakan ukuran keseluruhan prestasi perusahaan yang didefinisikan sebagai berikut:

\section{Laba $=$ Penjualan - Biaya}

\section{Metode Target Costing}

Target costing merupakan perbedaan antara harga jual produk atau jasa yang disajikan untuk pencapaian pangsa pasar dengan laba per satuan yang diinginkan perusahaan (Hansen \& Mowen, 2009). Samryn (2012) menjelaskan bahwa target costing adalah suatu metode penetapan biaya maksimum yang diperbolehkan untuk 
suatu produk baru dan kemudian mengembangkan suatu prototype yang dapat dibuat dan didistribusikan dengan harga sebesar nilai target biaya maksimum tersebut secara menguntungkan.

\section{Efisiensi Biaya}

Menurut Hasibuan (1984) efisiensi biaya adalah perbandingan yang terbaik antara input (masukan) dan output (hasil antara keuntungan dengan sumber-sumber yang dipergunakan) seperti halnya hasil optimal yang dicapai dengan penggunaan sumber yang terbatas. Adapun menurut Kamus Besar Ekonomi (2003) efisiensi adalah hubungan atau perbandingan antara faktor keluaran (output) barang dan jasa dengan masukan (input) yang langka di dalam suatu unit kerja atau ketetapan cara (usaha/kerja) dalam menjalankan sesuatu (dengan tidak membuang-buang waktu, tenaga dan biaya).

Menurut Kamus Besar Indonesia (2001) efisiensi merupakan ketetapan cara (usaha, kerja) dalam menjalankan sesuatu (dengan tidak membuang waktu, tenaga, biaya), kedayagunaan, ketepatgunaan, kesangkilan serta kemampuan menjalankan tugas dengan baik dan tepat (dengan tidak membuang waktu, tenaga dan biaya).

\section{Langkah-Langkah Penerapan Target Costing}

Metode target costing digunakan untuk mengefisiensikan biaya produksi sehingga perusahaan mampu mencapai target laba dengan optimal. Langkah-langkah dalam penerapan metode target costing menurut (Blocher et al., 2011) adalah sebagai berikut: 1) menentukan harga jual kripik setan di pasaran; 2) menghitung target laba yang diharapkan oleh perusahaan. Menghitung target laba dapat diperoleh menggunakan rumus berikut ini, yaitu target laba = laba yang diharapkan $(\%) \mathrm{x}$ harga jual.

Selanjutnya, 3) menentukan target biaya yang harus dikeluarkan oleh perusahaan dalam proses produksi kripik setan. Rumus yang digunakan yaitu, target biaya $=$ harga jual - laba yang diharapkan; 4) menghitung total biaya produksi yang efisien berdasarkan target biaya; 5) melakukan rekayasa nilai dari komponen biaya produksi yang dapat diturunkan tanpa merubah kualitas dari produk Kripset UMMI; 6) menghitung laba. Berikut merupakan rumus untuk menghitung total biaya produksi dan 
menghitung laba: a) total biaya produksi $=$ penjualan dalam setahun - laba yang diharapkan; b) total laba = pendapatan - biaya produksi dan lain-lain .

\section{METODE PENELITIAN}

Metode yang digunakan dalam penelitian ini adalah metode deskriptif dan kuantitatif. Metode deskriptif merupakan suatu metode yang digunakan dalam meneliti status sekelompok manusia, suatu objek, suatu set kondisi, suatu sistem pemikiran ataupun suatu kelas peristiwa pada masa sekarang. Tujuan dari penelitian deskriptif ini adalah untuk membuat deskripsi, gambaran atau lukisan secara sistematis, faktual dan akurat mengenai fakta-fakta, sifat-sifat serta hubungan antarfenomena yang diselidiki.

Menurut Sugiyono (2010) metode kuantitatif yaitu metode penelitian yang menggunakan data berupa angka-angka dan dianalisis menggunakan statistik. Berdasarkan definisi-definisi tersebut, maka dapat disimpulkan bahwa metode penelitian deskriptif dengan pendekatan kuantitatif bisa digunakan sebagai alat untuk mendeskripsikan atau menjelaskan permasalahan atau suatu kenyataan yang terjadi.

\section{HASIL PENELITIAN}

Biaya-Biaya yang Dikeluarkan oleh UKM Kripset UMMI Sukabumi dalam Satu Bulan

Tabel 1.

Biaya Bahan Baku

\begin{tabular}{lcccc}
\hline Keterangan & $\begin{array}{c}\text { Jumlah dalam 1 } \\
\text { Kali Produksi (Kg) }\end{array}$ & $\begin{array}{c}\text { Total 8 Kali } \\
\text { Produksi }\end{array}$ & $\begin{array}{c}\text { Harga } \\
\text { (Kg) }\end{array}$ & $\begin{array}{c}\text { Biaya yang Dikeluarkan } \\
\text { Per Bulan }\end{array}$ \\
\hline Keripik Jadi & 350 & & Rp. 10.500 & Rp. 29.400 .000 \\
Plastik & 45 & & Rp. 32.000 & Rp. 11.520 .000 \\
Cabai & 20 & Rp. 55.000 & Rp. 8.800 .000 \\
Bumbu & \multicolumn{2}{|c}{8 Kali } & Rp. 50.000 & Rp. 400.000 \\
\hline Total Biaya & & & Rp. 50.120.000 \\
\hline
\end{tabular}

(Sumber: UKM Kripset UMMI Sukabumi)

\section{Penetapan Biaya Produksi pada UKM Kripset UMMI Sukabumi}

Jenis-jenis biaya produksi yang dikeluarkan oleh UKM Kripset UMMI Sukabumi yaitu meliputi biaya bahan baku, biaya upah kerja dan biaya pengiriman. Berikut ini merupakan harga pokok produksi dari UKM Kripset UMMI Sukabumi: 
Tabel 2.

Biaya Produksi

\begin{tabular}{ll}
\hline \multicolumn{1}{c}{ Keterangan } & \multicolumn{1}{c}{ Jumlah } \\
\hline Biaya Bahan Baku & Rp. 50.120 .000 \\
Biaya Upah Kerja (20 Orang Pekerja) & Rp. 5.000.000 \\
Biaya Pengiriman & Rp. 3.200 .000 \\
\hline Total Biaya & Rp. 58.320.000 \\
\hline (Sumber: UKM Kripset UMMI Sukabumi) &
\end{tabular}

\section{Penjualan dalam Satu Bulan}

Laba kotor yang diperoleh oleh UKM Kripset UMMI dalam satu bulan adalah sebesar Rp. 60.000 .000 (detail perhitungan yaitu 7.500 x 8.000). Adapun perolehan laba bersih dalam satu bulan yaitu sebesar Rp. 1.680 .000 (detail perhitungan yaitu $60.000 .000-58.320 .000)$.

\section{Analisis Biaya Produksi Menggunakan Metode Target Costing}

\section{Menentukan Harga Pasar}

Menentukan harga pasar UKM Kripset UMMI ini bisa dilihat dari faktor internal dan faktor eksternal yaitu: 1) faktor internal, faktor ini tergantung pada pemilik usaha untuk mendapatkan besarnya laba yang diharapkan dan dipengaruhi oleh besarnya modal yang dikeluarkannya; 2) faktor eksternal ini bisa dilihat dari harga pesaing keripik dipasaran. Harga kripset di pasaran ini seharga Rp. 9.500 perbungkus.

\section{Menentukan Laba yang Diharapkan}

Berdasarkan perhitungan target laba, didapatkan hasil sebesar Rp. 2.250. Detail perhitungan adalah sebagai berikut:

Target Laba $=30 \% \times 7.500$

$$
=\text { Rp. } 2.250
$$

\section{Menghitung Target Biaya (Target Cost) pada Harga Pasar Dikurangi Laba yang Diharapkan}

Target biaya yang dikeluarkan UKM Kripset UMMI untuk satu kemasan adalah sebesar Rp. 5.250. Detail perhitungan adalah sebagai berikut:

Target Biaya $=7.500-2.250$

$$
=5.250
$$




\section{Penggunaan Rekayasa Nilai dalam Mengidentifikasi Cara untuk Menurunkan Biaya Produk}

Menerapkan metode target costing yaitu melakukan rekayasa nilai dari biaya produksi maupun biaya nonproduksi. Rekayasa nilai didapat dari mengurangi komponen-komponen biaya tanpa mengurangi kualitas dari produk. Komponen yang dapat direkayasa nilai dalam proses produksi Kripset UMMI yaitu biaya kemasan dan biaya tenaga kerja.

\section{Biaya Kemasan}

Biaya yang dikeluarkan oleh UKM Kripset UMMI sebelum rekayasa nilai adalah sebagai berikut:

Biaya Kemasan $=360 \mathrm{~kg}$ x Rp. 32.000

$$
=\text { Rp. } 11.520 .000
$$

Adapun setelah dilakukan rekayasa nilai, biaya yang diperoleh adalah sebagai berikut:

$$
\begin{aligned}
\text { Biaya Kemasan } & =360 \text { kg x Rp. } 30.000 \\
& =\text { Rp. } 10.800 .000
\end{aligned}
$$

Berdasarkan perhitungan biaya kemasan UKM Kripset UMMI, biaya sebelum rekayasa nilai yaitu sebesar Rp. 11.520.000. Kemudian biaya kemasan sesudah rekayasa nilai yaitu sebesar Rp. 10.800.000 dalam satu bulan. Biaya kemasan sesudah rekayasa mampu mengurangi biaya produksi sebesar Rp. 720.000 .

\section{Biaya Tenaga Kerja}

Biaya untuk upah tenaga kerja yang dikeluarkan oleh UKM Kripset UMMI sebelum rekayasa nilai adalah sebagai berikut:

$$
\text { Biaya }=8 \text { hari } \mathrm{x} 31.250 \times 20
$$$$
=\operatorname{Rp} .5 .000 .000
$$
berikut:

Adapun setelah dilakukan rekayasa nilai, biaya yang diperoleh adalah sebagai

$$
\begin{aligned}
\text { Upah } & =8 \text { hari } \times 30.000 \times 20 \\
& =\text { Rp. } 4.800 .000
\end{aligned}
$$


Berdasarkan hasil perhitungan biaya tenaga kerja UKM Kripset UMMI, biaya sebelum reakayasa nilai adalah sebesar Rp. 5.000.000. Setelah dilakukan rekayasa nilai, biaya tenaga kerja menjadi Rp. 4.800.00. Rekayasa nilai ternyata mampu mengurangi biaya upah kerja sebesar Rp. 200.000.

\section{Menentukan Laba Bersih}

Setelah dilakukan perekayasaan biaya, maka perkiraan laba bersih yang akan diperoleh UKM Kripset UMMI adalah sebagai berikut:

$$
\begin{aligned}
\text { Laba } & =60.000 .000-54.200 .000 \\
& =\text { Rp. } 5.800 .0000
\end{aligned}
$$

\section{Perbandingan Perhitungan Biaya Produksi Menurut Perusahaan dengan}

\section{Perhitungan Biaya Produksi Menggunakan Metode Target Costing}

Tabel 3.

\begin{tabular}{|c|c|c|}
\hline Keterangan & Menurut Perusahaan & Target Costing \\
\hline Keripik Jadi & Rp. 29.400 .000 & Rp. 29.400 .000 \\
\hline Plastik & Rp. 11.520 .000 & Rp. 10.800 .000 \\
\hline Cabai & Rp. 8.800 .000 & Rp. 8.800 .000 \\
\hline Bumbu & Rp. 400.000 & Rp. 400.000 \\
\hline
\end{tabular}

Biaya Bahan Baku

Tabel 4.

Biaya Tenaga Kerja

\begin{tabular}{ccc}
\hline Keterangan & Menurut Perusahaan & Target Costing \\
\hline Biaya Tenaga Kerja & Rp. 5.000.000 & Rp. 4.800.000 \\
\hline
\end{tabular}

Tabel 5.

Biaya Pengiriman

\begin{tabular}{cc}
\hline Keterangan & Menurut Perusahaan \\
\hline Biaya Pengiriman & Rp. 3.2000.000 \\
\hline
\end{tabular}

Tabel 6.

Total Biaya

\begin{tabular}{ccc}
\hline Keterangan & Menurut Perusahaan & Target Costing \\
\hline Total Biaya & Rp. 58.320.000 & Rp. 54.200.000 \\
\hline
\end{tabular}

Berdasarkan data tersebut biaya produksi sebelum menggunakan metode target costing perusahaan mengeluarkan sebesar Rp. 58.320.000 dalam satu bulan. Sedangkan 
setelah menggunakan metode target costing perusahaan mengeluarkan biaya produksi sebesar Rp. 54.200.000 maka dari itu perusahaan bisa mengefesiensikan biaya sebesar Rp. 4.120.000 dan pendapatan dalam satu bulan pun bisa mencapai Rp. 5.800.000.

\section{PEMBAHASAN}

Salah satu hal yang sering menjadi permasalahan bagi perusahaan adalah masalah harga. Menurut Rudianto (2013) harga jual yang terlalu tinggi akan membuat masyarakat tidak berminat untuk membeli atau mengurangi jumlah pembelian produk, sehingga perusahaan tidak akan memperoleh laba yang cukup dan sebaliknya, harga jual yang terlalu rendah dapat membuat perusahaan tidak mampu mencapai laba usaha sesuai dengan yang diharapkan.

Penerapan pasar bebas secara global tentu akan menimbulkan persaingan dalam sektor perdagangan yang semakin tinggi. Dengan berlakunya pasar ini akan memudahkan masyarakat atau perusahaan dari negara lain untuk memperdagangkan hasil produk mereka ke Indonesia dengan batasan yang tidak terlalu banyak. Penerapan Masyarakat Ekonomi ASEAN (MEA) secara otomatis akan mendorong perusahaan untuk lebih berinovasi pada produk usaha mereka, baik itu yang berupa barang, jasa maupun tenaga kerja agar dapat bersaing dan meraup banyak keuntungan. Khususnya produk barang dagang, perusahaan harus menghasilkan produk yang berkualitas namun dengan harga yang terjangkau. Hal ini tentu akan menarik hati para konsumen. Tetapi tidak semua perusahaan khususnya perusahaan dagang mampu menciptakan atau memproduksi barang dagang mereka dengan tetap mempertahankan kualitas barang dan memiliki harga yang terjangkau namun perusahaan tetap dapat mencapai keuntungan sesuai dengan yang diharapkan (Longdong, 2016).

Perusahan perlu mempertimbangkan cara yang terbaik agar dapat memperoleh laba seoptimal mungkin di tengah ketatnya persaingan. Oleh karena itu, perusahaan harus melakukan penerapan sistem pengendalian biaya total dengan kalkulasi biaya target (target costing) yang merupakan metode pengerjaan terbalik dengan melakukan penentuan harga di pasar terlebih dahulu, kemudian baru menentukan biaya. Target costing merupakan satu metode perhitungan yang efektif untuk mengurangi biaya (Juwita \& Satria, 2017). 
Berdasarkan hasil penelitian, setelah diterapkannya target costing pada sistem operasional UKM Kripset UMMI Sukabumi, UKM ini mampu mengefisiensikan biaya produksi dan meningkatkan perolehan laba secara signifikan. Hal ini sejalan dengan hasil penelitian Longdong (2016) yang juga menemukan bahwa metode target costing berpengaruh terhadap biaya produksi, dimana setelah CV. Sinar Mandiri menerapkan metode tersebut, perusahaan mampu melakukan pengendalian biaya dengan menggunakan rekayasa nilai dan terbukti bahwa perusahaan mampu mengurangi biaya produksinya dan dapat mencapai target laba bahkan lebih dari yang diharapkan.

\section{SIMPULAN}

Penetapan biaya produksi pada UKM Kripset UMMI Sukabumi sebelumnya masih menggunakan metode manual, sehingga biaya produksi terus meningkat dan laba yang diperoleh belum optimal. Namun setelah diterapkan target costing, biaya produksi bisa diefisiensikan dan laba mampu ditingkatkan secara optimal.

\section{DAFTAR PUSTAKA}

Ahmad, F., \& Abdullah, W. (2009). Akuntansi Biaya, Edisi 2. Jakarta: Salemba Empat Blocher, E. J., Stout, D. E., \& Cokins, G. (2011). Manajemen Biaya Penekanan Strategis, Jilid 1, Edisi 5. Jakarta: Salemba Empat

Bustami, B., \& Nurlela, N. (2010). Akuntansi Biaya. Yogyakarta; Graha Ilmu

Copeland, T. E., \& Weston, J. F. (1992). Financial Theory and Corporate Policy, 5thEd. USA: Addison-Wesley Publishing Company, Inc

Hanafi, M. M. (2010). Manajemen Keuangan, Cetakan Kelima. Yogyakarta: BPFE

Hansen, H., \& Mowen, M. (2004). Manajemen Biaya, Edisi Bahasa Indonesia, Buku Kedua. Jakarta: Salemba Empat

Hansen, H., \& Mowen, M. (2009). Akuntansi Manajerial, Buku 1, Edisi 8. Jakarta: Salemba Empat

Haryono, Y. (2009). Dasar-Dasar Akuntansi. Yogyakarta: STIE YKPN

Hasibuan, M. S. P. (1984). Manajemen Dasar, Pengertian dan Masalah. Jakarta: Gunung Agung

Juwita, R., \& Satria, M. R. (2017). Penerapan Target Costing dalam Upaya Efisiensi Biaya Produksi untuk Peningkatan Laba Produk. Jurnal Kajian Akuntansi, 1(2), 184-193

Kamaludin, K., \& Indriani, R. (2012). Manajemen Keuangan, Edisi Revisi. Bandung: CV. Bandar Maju

Kamus Besar Bahasa Indonesia. (2001). Pengertian Efisiensi, Tujuan, Macam-macam, Unsur dan Penyebab. https://www.pahlevi.net/pengertian-efisiensi/ 
Kamus Besar Ekonomi. (2003). Pengertian Efisiensi, Tujuan, Jenis dan Contohnya. https://www.kanal.web.id/pengertian-efisiensi-tujuan-jenis-dan-contohnya

Kuswadi, K. (2005). Meningkatkan Laba Melalui Pendekatan Akuntansi Keuangan dan Akuntansi Biaya. Jakarta: PT. Elex Media Komputindo

Longdong, F. M. (2016). Penerapan Target Costing dalam Perencanaan Biaya Produksi pada CV. Sinar Mandiri. Jurnal Emba, 4(1), 1409-1418

Mulyadi, M. (2012). Akuntansi Biaya. Yogyakarta: UPP STIM YKPN

Nafarin, M. (2009). Penganggaran Perusahaan. Jakarta: Salemba Empat

Riyanto, B. (2013). Dasar-Dasar Pembelanjaan Perusahaan, Edisi Keempat. Yogyakarta: BPFE-Yogyakarta

Rudianto, R. (2013). Akuntansi Manajemen. Jakarta: Erlangga

Samryn, L. M. (2012). Akuntansi Manajemen Informasi Biaya untuk Mengendalikan Aktivitas Operasi dan Investasi, Edisi Pertama. Jakarta: Kencana Prenada Media Group

Sugiyono, S. (2010). Metode Penelitian Bisnis (Pendekatan Kuantitatif, Kualitatif dan R\&D). Bandung: Alfabeta

Sutrisno, S. (2013). Manajemen Keuangan: Teori Konsep dan Aplikasi, Cetakan Ke-9. Yogyakarta: Ekonisis 